\title{
VARIATION IN DRONE MATING FLIGHT TIMES AMONG COMMERCIAL HONEY BEE STOCKS *
}

\author{
Gareth A. ROWELL, Orley R. TAYLOR, Jr., and Sarah J. LOCKE ** \\ Department of Entomology, University of Kansas \\ Lawrence, Kansas, 66045 U.S.A.
}

\begin{abstract}
SUMMARY
Variation was measured among and within commercial honey bee stocks in the time of day that drones fly. Ten commercial stocks, representing three honey bee races and one racial hybrid, were surveyed. Results indicate that substantial variation existed among the 45 colonies. Significant differences among mean departure times were obtained on 16 out of 20 observation days. Significant differences in departure times were observed among colonies of different races but were also observed among colonies of the same race, and even among colonies of the same commercial stocki. No one race or commercial stock could be described as early- or late-flying.

Differences of 30 minutes or more in mean departure times occurred over a wide range of temperatures, light intensities, windspeeds, and cloud conditions. Mean departure times of drones were significantly correlated with daily temperature means $(\mathrm{r}=.626, \mathrm{P}<.05)$. Departure time was not significantly correlated with the age of drones $(r=-.027, \mathrm{P}>.05)$; however duration of flight activity (as measured by the magnitude of within-colony variances) increased slightly with drone age $(\mathrm{r}=.174, \mathrm{P}<.05)$.
\end{abstract}

\section{INTRODUCTION}

This is a study of the variation among and within commercial honey bee stocks in the time of day that drones fly. The questions, when do drones fly, and how varied are drone flight times among commercial stocks, arose from studies on the mating biology of African and European bees in northern South America. TAYLOR, KINGSOLVER, and OTIS (in press) indicated that several factors may contribute to the persistence of the African phenotype and to the Africanization of European bees in northern South America. These factors include (1) African bees are more uniformly d:stributed throughout habitats of northern South America.

* Contribution 1917 from the Department of Entomology, University of Kansas, Lawrence, Kansas, 66045 U.S.A.

** Present address : Department of Entomology, University of California, Davis, California 95616 U.S.A. 
(2) African population densities are much higher. (3) The mating system of honey bees is one of outbreeding. Queens tend to fly beyond the flight distribution of drones from the same colony. (4) African drones and queens fly significantly later in the afternoon than European drones and queens. These four factors combine to give the African drone a mating advantage over the European drone (TAYLOR, KINGSOLVER, and OTIS, in press).

In theory, it should be possible to reverse the African drone mating advantage by (1) increasing population sizes of European drones relative to African drones, (2) making the distribution of European colonies more uniform (more apiary sites with fewer colonies per site), and (3) developing a commercial bee stock that produces late-flying drones which would be more likely to mate with African queens.

In order to develop a commercial stock having late-flying drones, colonies with such late fliers must be identified and incorporated into a bee-breeding program. This breeding program will require unprecedented emphasis on the biological characteristics of drones, as well as on the commercial value of the entire colony. The present study measures available variation in flight times of drones as a first step towards such a program.

Drone flight behavior has been well documented, and there have been numerous studies dealing with flight frequency and flight duration. Several generalizations can be made : (1) Drone flight activity is usually limited to the afternoon (Mikhailov, 1928 ; Oertel, 1956). (2) Peak flight activity generally occurs between $1400 \mathrm{~h}$ and $1630 \mathrm{~h}$ (Howell and Usinger, 1933 ; LAVReKHIN, 1960 ; RUTTNER, 1966 ; Bol'SHAKova, 1978) however TABER (1964) reported flights of almost two hours earlier in studies conducted early in the drone season. (3) Temperature, light intensity, windspeed, cloudiness, and possibly humidity and barometric pressure, influence the time of day that drones fly (MiKHaIlov, 1928 ; Howell and Usinger, 1933 ; Drescher, 1969 ; TuchashVili, 1969'; Bol'shakova, 1978 ; Verbeek and Drescher, 1984). (4) Flight activity shifts either earlier or later as the secson progresses (Mikhailov, 1928 ; TABER, 1964 ; Bol'Shakova, 1978). (5) Both temperature and daylength may affect seasonal shifts in flight times (TABER, 1964). (6) Drones usually take their first mating flights seven to eight days after emergence. (7) Drones rarely fly before the sixth day (WITHERELL, 1971). (8) The first flights of young drones last only a few minutes or less and appear to serve primarily for orientation (HOWELL and USINGER, 1933). (9) Orientation by drones to mating sites or congregation areas is probably accomplished by learning landmarks and surface topography (RUTTNER, 1966; RUTTNER and RUtTNER, 1966). (10) Orientation towards the flying queen is both visual and pheromonal (Gary, 1963 ; Butler and Fairey, 1964 ; van PraAgh et al., 1980). (11) Drones usually fly $10 \mathrm{~m}$ to $40 \mathrm{~m}$ above the ground, higher on calm days, lower on windy days (RUTTNER, 1966). 
(12) Drones generally take three or more mating flights in an afternoon under favorable weather conditions (Howell and Usinger, 1933). Drescher (1969) reported as many as five to eight flights per drone during one afternoon. (13) Inbreeding is disruptive since both flight frequency and flight duration of drones decrease according to the degree of inbreeding in the mother queen (MoRITZ, 1981). (14) Drone life span under normal conditions is highly variable. DreSCHER (1969) obtained a mean life span of $22.8 \pm 8.0$ day during mid-summer studies. FUKUDA and OHTANi (1977) noted that life span is short in the summer (13.9 days) as compared to autumn (32.1-42.5 days) and questioned the reality of autumn drone slaughter by worker bees. High survivorship in autumn is probably associated with reduced flight activity. High mortality in the summer is probably related to both high levels of flight activity and meteorological extremes associated with resource stress on the colony.

Comparative studies on the mating flight times of drones have been conducted on different species of Apis and on different races of Apis mellifera. Distributions of drone flight times of different $A$ pis species occurring sympatrically are distinct and well-separated (Koeniger and Wijayagunasekera, 1976). Drones of Apis cerana have a flight period which is consistently later in the afternoon than those of A pis mellifera (LAVReKHIN, 1960). Comparatively smaller differences in drone flight times have been found among different races of Apis mellifera (DRESCHER, 1969 ; Tuchashvili, 1969 ; TAYlor, Kingsolver and OTIS, in press). These studies, taken together, suggest that substantial variation in drone flight times exists both among Apis species and within Apis mellifera. The objective of the present study has been to experimentally quantify this variation for Apis mellifera.

\section{MATERIALS AND METHODS}

Ten stocks were selected from the following bee races : Apis mellifera carnica (CAR - Stocks A, B, and C), A. m. caucasica (CAU - Stocks D, E, and F), A. m. ligustica (LIG - Stocks G, H, and I), and $A . m$. mellifera - ligustica (MEL-LIG - Stock J). A race, for purposes in this study, is defined as a group of populations which is believed (but not shown) to have historically shared geographic origins. Although MEL-LIG is more accurately described as a racial hybrid, for simplicity, it is called a race throughout this paper. Queens, representing diverse honey bee stocks, were purchased from commercial queen producers who operate in the southern and western United States. Stocks do not necessarily originate from these regions. In one instance, a commercial stock (Stock J) has been maintained by shipment of semen from England to a queen producer in U.S.A. (ADAM and Connor, 1984). Between six and 12 queens were purchased from each queen producer. Queens arrived in April and early May, 1983, and were subsequently introduced into standard two-story hives.

The five experimental apiaries used in this study each included colonies from four or more of the stocks mentioned above. Apiaries were located near Lawrence, Kansas $\left(38.58^{\circ} \mathrm{N}, 95.14^{\circ} \mathrm{W}\right)$. The distribution of stocks and races in experimental apiaries was constrained by (1) the need to observe three or more colonies at the same apiary within a given day and (2) the need to have 
drones of the same age during each observation period, in order to minimize this non-genetic factor. To obtain drones of similar ages, queens must lay eggs on drone combs simultaneously. Occasionally, in a number of colonies, queens failed to do this. Colonies of queens that delayed egg laying were either reassigned to new apiaries or simply omitted from the study. Because of such asynchrony, failure of some queens to produce enough drones, and loss of drone brood to chalk brood disease, drone flight observations were obtained from only 45 of the 60 colonies intended for this study.

Physical differences among colonies at each apiary were minimized in order to reduce non-genetic variation in mean departure times. Hive entrances were oriented in the same direction (generally southward). Wind exposure within each apiary was approximately equal. Also, differences in sunlight and shading were minimized.

Drone emergence was synchronized by placing drone combs into the centers of brood nests of each colony. Queens generally laid eggs on drone combs within two days following drone comb insertion. Colonies were revisited 7-14 days later and combs inspected for presence of brood. At this time, drone emergence dates were predicted.

Drones were marked in order to identify age and colony of origin. Two days before emergence, the drone comb and one frame of young bees and unsealed larvae were placed above a queen excluder over the brood chamber of each hive. All previously emerged drones were removed from both frames at this time. Each day, the:eafter, newly emerged drones were marked on the notum with either one or two color dots of quick-drying enamel paint. Four cohorts (100 drones per cohort) were marked, one per day, in each colony. The total number of cohorts differed from four, on occasion, either when almost all drones emerged within 1-2 days, or when emergence extented for several days.

The variable of primary concern in this study was the frequency of drone departures over time. Departure time (to the nearest minute) and drone ages were recorded by observers sitting adjacent to colony entrances from $1400 \mathrm{~h}$ to $1800 \mathrm{~h}$ CDT. Data were analyzed using the University of Kansas Academic Computer System and also using a Zenith Data Systems Z-100 microcomputer. Statistical descriptions and one-way analyses of variance were obtained from BMDP-7D statistical package (Drxon, 1981). Multiple comparisons among pairs of means were calculated using the Games and Howell method (Program MCHETV - SOKaL and ROHLF, 1981; ROHLF, 1983). Due to lack of homogeneity of within-colony variances, the statistics used here for the overall analysis and subsequent multiple comparisons of means are approximate tests that are robust under conditions of inequality of variances (Brown and ForsYtHe, 1974 a ; SOKal and ROHLF, 1981). Equality of variances were tested using the Levene $\left(W_{b}\right)$ statistic (BroWN and ForsYTHE, $1974 \mathrm{~b}$ ).

Meteorological information (including temperature, incident light intensity, cloudiness, and windspeed) was recorded at the apiary site every 15 minutes during each observation period. Observations of drone flight departures were taken on queenright colonies housed in standard two-story hives and also from queenless colonies housed in five-frame hives (nucleus colonies). Queenless nucleus colonies are much more likely to retain drones than are queenright standard colonies during periods of resource stress. Observations were taken on standard colonies until late in the drone season (late June) when bees were less likely to retain drones that had been reared and reintroduced into the colony. Rejection of drones and high mortality rates of drones necessitated the use of nucleus colonies from late June to mid July. The number of colonies tested per stock (table 1), which were queenright and queenless respectively, were : Stock A, 1, 4; Stock B, 1, 2; Stock C, 2, 2; Stock D, 3, 2; Stock E, 2, 2; Stock F, 0, 3; Stock G, 3, 2; Stock H, 4, 2 ; Stock I, 2, 1; and Stock J, 5, 2 .

\section{RESULTS}

Substantial differences in mean departure times and within-colony var:ances of departure times were commonly found among colonies compared on the same 
TABL. 1. - Descriptive statistics, approximate one-way analysis of variance (Brown - Forsythe modifier F-statistic, $F^{*}$, and tests for equal variance Levene's statistic, $W_{o}$ )

\begin{tabular}{|c|c|c|c|c|c|c|}
\hline Date & Race & $\begin{array}{l}\text { Stock- } \\
\text { colony }\end{array}$ & $\begin{array}{l}\text { Mean } \\
\text { departure } \\
\text { time }\end{array}$ & $s^{2}$ & $\mathrm{n}$ & $\begin{array}{c}\text { One - Way } \\
\text { Anova } \\
\text { Equal variances }\end{array}$ \\
\hline 28 May & $\begin{array}{c}\text { MEL-LIG } \\
\text { LIG } \\
\text { CAU }\end{array}$ & $\begin{array}{l}J-4 a \\
H-4 \\
D-3\end{array}$ & $\begin{array}{l}127.90 b \\
141.59 \\
138.35\end{array}$ & $\begin{array}{l}1937.32 \\
2030.31 \\
2117.01\end{array}$ & $\begin{array}{r}1259 \\
923 \\
1233\end{array}$ & $\begin{array}{c}F^{*}=28.82^{* * * \mathrm{c}} \\
\mathrm{W}_{0}=.76 \mathrm{c} \\
\end{array}$ \\
\hline 3 June & $\begin{array}{c}\text { LIG } \\
\text { MEL-LIG } \\
\text { LIG }\end{array}$ & $\begin{array}{l}\text { G-1 } \\
\text { J-3 } \\
\text { H-2 }\end{array}$ & $\begin{array}{l}122.68 \\
128.04 \\
120.27\end{array}$ & $\begin{array}{l}2833.75 \\
3113.08 \\
2598.55\end{array}$ & $\begin{array}{l}713 \\
806 \\
837\end{array}$ & $\begin{array}{c}F^{*}=4.52^{*} \\
W_{0}=6.55^{* *} \\
-\end{array}$ \\
\hline 6 June & $\begin{array}{c}\text { MEL-LIG } \\
\text { MEL-LIG } \\
\text { LIG }\end{array}$ & $\begin{array}{l}\mathbf{J}-3 \\
\mathbf{J}-4 \\
\mathrm{H}-4\end{array}$ & $\begin{array}{l}154.97 \\
159.57 \\
154.47\end{array}$ & $\begin{array}{r}1433.15 \\
873.44 \\
1692.25\end{array}$ & $\begin{array}{l}580 \\
465 \\
902\end{array}$ & $\begin{array}{c}\mathbf{F}^{*}=3.33^{*} \\
\mathrm{~W}_{0}=39.45^{* * * *} \\
-\end{array}$ \\
\hline 7 June & $\begin{array}{l}\text { LIG } \\
\text { LIG } \\
\text { CAU }\end{array}$ & $\begin{array}{l}\text { G-1 } \\
\text { H-2 } \\
\text { D-3 }\end{array}$ & $\begin{array}{l}135.34 \\
118.67 \\
151.41\end{array}$ & $\begin{array}{l}2600.49 \\
3362.84 \\
3123.69\end{array}$ & $\begin{array}{r}643 \\
679 \\
1388\end{array}$ & $\begin{array}{c}\mathrm{F}^{*}=83.41 * * * \\
\mathrm{~W}_{0}=8.97 * * * \\
-\end{array}$ \\
\hline 9 June & $\begin{array}{l}\text { MEL-LIG } \\
\text { MEL-LIG } \\
\text { LIG }\end{array}$ & $\begin{array}{l}\text { J-4 } \\
\text { J-3 } \\
\text { H-4 }\end{array}$ & $\begin{array}{l}166.48 \\
167.08 \\
169.86\end{array}$ & $\begin{array}{l}1075.84 \\
1751.67 \\
1895.99\end{array}$ & $\begin{array}{l}610 \\
618 \\
707\end{array}$ & $\begin{array}{c}\mathrm{F}^{*}=1.39 \\
\mathrm{~W}_{0}=28.33 * * * \\
-\end{array}$ \\
\hline 15 June & $\begin{array}{c}\text { MEL-LIG } \\
\text { CAU } \\
\text { CAU }\end{array}$ & $\begin{array}{l}\text { J-1 } \\
\text { D-5 } \\
\text { D-6 }\end{array}$ & $\begin{array}{l}160.23 \\
152.35 \\
154.40\end{array}$ & $\begin{array}{l}2014.93 \\
1709.91 \\
1376.78\end{array}$ & $\begin{array}{l}319 \\
415 \\
615\end{array}$ & $\begin{array}{c}F^{*}=3.41^{*} \\
W_{0}=8.37^{* * *} \\
-\end{array}$ \\
\hline 17 June & $\begin{array}{c}\text { LIG } \\
\text { MEL-LIG } \\
\text { CAU } \\
\text { CAU }\end{array}$ & $\begin{array}{l}\mathrm{G}-4 \\
\mathrm{~J}-1 \\
\mathrm{D}-5 \\
\mathrm{D}-6\end{array}$ & $\begin{array}{l}199.13 \\
196.41 \\
197.27 \\
180.08\end{array}$ & $\begin{array}{r}658.49 \\
1209.02 \\
1091.31 \\
514.75\end{array}$ & $\begin{array}{l}514 \\
270 \\
265 \\
505\end{array}$ & $\begin{array}{c}\mathrm{F}^{*}=41.02 * * * \\
\mathrm{~W}_{0}=32.40^{* * *} \\
-\end{array}$ \\
\hline 24 June & $\begin{array}{c}\text { LIG } \\
\text { MEL-LIG } \\
\text { CAU } \\
\text { CAU }\end{array}$ & $\begin{array}{l}\text { G-4 } \\
\text { J-1 } \\
\text { D-5 } \\
\text { D-6 }\end{array}$ & $\begin{array}{l}205.20 \\
197.33 \\
193.66 \\
199.70\end{array}$ & $\begin{array}{r}1583.24 \\
1764.59 \\
1106.63 \\
908.12\end{array}$ & $\begin{array}{l}481 \\
165 \\
218 \\
166\end{array}$ & $\begin{array}{c}\mathrm{F}^{*}=5.70^{* * *} \\
\mathrm{~W}_{0}=12.57^{* * * *} \\
-\end{array}$ \\
\hline 29 June & $\begin{array}{l}\text { CAU } \\
\text { CAU } \\
\text { CAU }\end{array}$ & $\begin{array}{l}\text { E4-J nuc } \\
\text { E-4 nuc } \\
\text { E-4 }\end{array}$ & $\begin{array}{l}227.87 \\
216.92 \\
215.09\end{array}$ & $\begin{array}{l}639.38 \\
918.94 \\
711.13\end{array}$ & $\begin{array}{l}626 \\
581 \\
248\end{array}$ & $\begin{array}{c}\mathbf{F}^{*}=31.69 * * * \\
\mathbf{W}_{0}=14.46^{* * * *} \\
\end{array}$ \\
\hline 30 June & $\begin{array}{l}\text { LIG } \\
\text { CAU } \\
\text { CAU } \\
\text { CAR }\end{array}$ & $\begin{array}{l}\mathrm{H}-3 \\
\mathrm{E}-4 \\
\mathrm{E}-5 \\
\mathrm{C}-1\end{array}$ & $\begin{array}{l}210.54 \\
199.21 \\
208.65 \\
179.90\end{array}$ & $\begin{array}{r}719.69 \\
794.34 \\
760.88 \\
1041.87\end{array}$ & $\begin{array}{l}410 \\
135 \\
238 \\
134\end{array}$ & $\begin{array}{c}\mathrm{F}^{*}=40.97^{* * *} \\
\mathrm{~W}_{0}=3.95^{* *} \\
\end{array}$ \\
\hline
\end{tabular}

a Letter represents commercial stock, number indicates individual colony. Colonies queenright and more than ca. 10000 worker bees except where labeled «nuc». Nuc or nucleus colonies were tqueenless with 3000-5000 worker bees.

b Minutes after $13.30 \mathrm{~h}$ CDT.

c $* * *, \mathbf{P}<.001 ; * *, .001 \leq \mathbf{P} .01 ; *, .01 \leq \mathbf{P}<.05$. 
Table 1. - (continued)

\begin{tabular}{|c|c|c|c|c|c|c|}
\hline Date & Race & $\begin{array}{l}\text { Stock- } \\
\text { colony }\end{array}$ & $\begin{array}{l}\text { Mean } \\
\text { departure } \\
\text { time }\end{array}$ & $\mathrm{s}^{2}$ & $\mathrm{n}$ & $\begin{array}{c}\text { One - Way } \\
\text { Anova } \\
\text { Equal variances }\end{array}$ \\
\hline \multirow[t]{4}{*}{2 July } & MEL-LIG & $J-6$ & 169.22 & 1434.74 & 115 & \\
\hline & CAR & A-4 & 177.18 & 1537.11 & 89 & $F^{*}=8.29^{* * * *}$ \\
\hline & CAR & B-2 & 152.20 & 1255.92 & 92 & $\mathrm{~W}_{0}=2.55$ \\
\hline & LIG & $1-3$ & 160.08 & 963.17 & 71 & - \\
\hline \multirow[t]{4}{*}{4 July } & MEL-LIG & $\mathrm{J}-7$ & 150.49 & 1632.64 & 107 & \\
\hline & CAR & $\dot{\mathrm{B}}-2$ & 149.54 & 3496.71 & 393 & $F^{*}=42.01^{* * * *}$ \\
\hline & LIG & I -5 & 163.03 & 2552.37 & 295 & $\mathrm{~W}_{0}=25.29 * *$ \\
\hline & CAR & $\mathrm{C}-\mathrm{K}$ & 188.81 & 1922.38 & 311 & - \\
\hline \multirow[t]{3}{*}{5 July } & MEL-LIG & $\mathrm{J}-2$ nuc & 173.24 & 2023.20 & 352 & $F^{*}=6.44^{* *}$ \\
\hline & LIG & H-1 & 176.63 & 1456.26 & 348 & $W_{0}=5.35^{* *}$ \\
\hline & LIG & H-1 nuc & 165.98 & 1753.93 & 403 & - \\
\hline \multirow[t]{4}{*}{6 July } & LIG & G-2 nuc & 196.55 & 1987.47 & 42 & \\
\hline & LIG & G-3 nuc & 194.92 & 800.44 & 261 & $F^{*}=7.85 * *$ \\
\hline & LIG & G-3 & 204.03 & 959.33 & 166 & $W_{0}=25.25^{* * * *}$ \\
\hline & CAU & F-5 nuc & 187.15 & 1661.79 & 331 & - \\
\hline \multirow[t]{3}{*}{7 July } & CAU & D-2 nuc & 188.25 & 1937.23 & 240 & $F^{*}=79.78^{* * * *}$ \\
\hline & CAR & C-2 nuc & 143.92 & 2077.17 & 428 & $\mathrm{~W}_{0}=2.07$ \\
\hline & CAR & C-3 nuc & 163.35 & 1750.25 & 261 & - \\
\hline \multirow[t]{3}{*}{9 July } & MEL-LIG & $J-6$ & 186.37 & 1554.33 & 82 & $F^{*}=2.39$ \\
\hline & CAR & A-4 & 183.88 & 1130.91 & 68 & $\mathrm{~W}_{0}=1.82$ \\
\hline & LIG & $\mathrm{I}-3$ & 173.14 & 1540.88 & 63 & - \\
\hline \multirow[t]{4}{*}{11 July } & MEL-LIG & $\mathrm{J}-2$ nuc & 212.30 & 1865.89 & 43 & \\
\hline & CAU & D-4 nuc & 221.93 & 2294.60 & 238 & $F^{*}=2.45$ \\
\hline & $\mathrm{CAU}$ & F-5 nuc & 215.28 & 920.03 & 106 & $\mathrm{~W}_{0}=8.58 \% *$ \\
\hline & CAU & F-6 nuc & 210.43 & 1322.41 & 101 & - \\
\hline \multirow[t]{4}{*}{12 July } & LIG & H-5 nuc & 215.06 & 1489.81 & 241 & \\
\hline & CAR & B-4 nuc & 229.33 & 1248.56 & 256 & $\mathbf{F}^{*}=6.56^{* * *}$ \\
\hline & LIG & I-6 nuc & 220.56 & 1449.48 & 308 & $\mathrm{~W}_{0}=1.70$ \\
\hline & CAU & F-KS nuc & 221.85 & 1110.29 & 188 & - \\
\hline \multirow[t]{4}{*}{14 July } & CAR & A-1 nuc & 171.62 & 2765.39 & 145 & \\
\hline & CAR & A-2 nuc & 166.22 & 2357.10 & 235 & $F^{*}=1.42$ \\
\hline & CAR & A-3 nuc & 161.82 & 2169.98 & 222 & $\mathrm{w}_{0}=1.49$ \\
\hline & CAR & B-1 nuc & 168.86 & 2731.00 & 419 & - \\
\hline \multirow[t]{4}{*}{15 July } & MEL-LIG & J-9 nuc & 155.22 & 1334.88 & 27 & \\
\hline & CAR & A-K nuc & 200.98 & 1588.02 & 51 & $F^{*}=12.59 \% * *$ \\
\hline & CAR & A-2 nuc & 182.10 & 1661.95 & 175 & $\mathrm{~W}_{0}=3.32^{*}$ \\
\hline & CAR & B-1 nuc & 196.68 & 1859.42 & 221 & - \\
\hline
\end{tabular}


day. Repeatability of drone behavior was observed in the means of colonies observed more than once.

From a total of 20 observation days, comparing drone flight activity of three to four colonies on each day, significant differences in mean departure times were obtained on 16 days ( $\mathrm{F}^{*}$ values, $\mathrm{P}<.05$, table 1 ). Among comparisons of standard size colonies, means differed significantly on 10 out of 12 observation days, seven of these having P-values of less than .001 (including 28 May, 7, 17, 24 and 30 June, 2 and 4 July).

Mean departure times, from nucleus colonies, differed significantly on three of five observation days ( 7,12 and $15 \mathrm{July})$. On days where standard colonies were compared with either two or three nucleus colonies, significant differences among colonies were also detected (29 June and 6 July).

Drone flight-time comparisons were made between standard colonies and queenless nucleus colonies (which contained drones and workers from standard colonies). Drones of nucleus colonies flew either earlier (5 July), or at similar times (29 June, 6 July) as drones from their respectîve standard colonies.

Consistencies in flight-time means were seen among colonies compared more than once, especially on days when flight-time means were well dispersed (i.e., days having significant differences among mean departure times). On two such days (17 and 24 June), colony G-4 drones repeatedly flew later than those of J-1, D-5, or D-6. Colony B-2 drones flew earliest of four colonies on 2 and 4 July. Similarly, colony H-4 flew latest of three colonies on both 28 May and 9 June.

Significant differences in within-colony variances (Levene's test, $\mathrm{W}_{0}$, for equal variances) were detected on 14 out of 20 observation days (table 1). Among standard colony comparisons, significant differences were found on nine out of 12 observation days, seven of which were highly significant $(6,7,9,15,17$, and 24 June, and also 4 July). In comparisons of nucleus colonies, only one observation day out of five showed significant inequalities of within-colony variances (11 July). And finally, among standard/nucleus colony comparisons, significantly different within-colony variances were observed on every observation day ( 29 June, 5 and 6 July). Drones of nucleus colonies compared against related standard colonies had either larger variances (29, June, 5 July) or smaller variances (6 July).

Significant differences $(\mathrm{P}<.05)$ between pairs of means were found among colonies of different races (table 2 : a., d., f., g., h., i., k., m., n., o., and p.), among colonies of different commercial stocks of the same race (table $2: \mathrm{d}$., $\mathrm{j}$., and $\mathrm{k}$.), and among colonies of the same commercial stock (table $2: \mathrm{f} ., 1 .$, and $\mathrm{n}$ ). By ranking the means within each day (early, intermediate, or late), and comparing all days collectively where significant differences $\left(\mathrm{F}^{*}\right.$ test, $\mathrm{P}<.01$ ) occurred, some stocks had predominantly intermediate means whereas others had far more extreme flight times, both early and late (see figure 1). 
TABL. 2. - Approximate tests of equality among pairs of mean departure times (minutes) using the Games and Howell method

a) $28 \mathrm{May}$

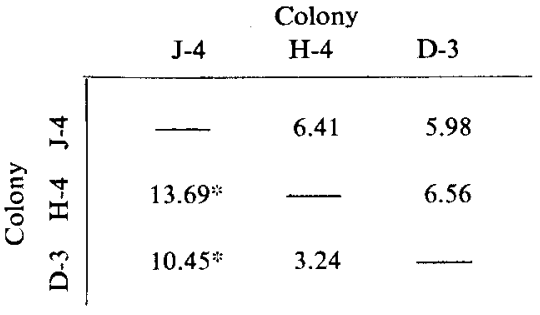

c) 6 June

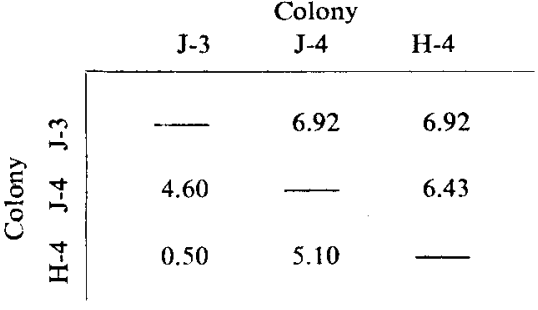

c) 15 June

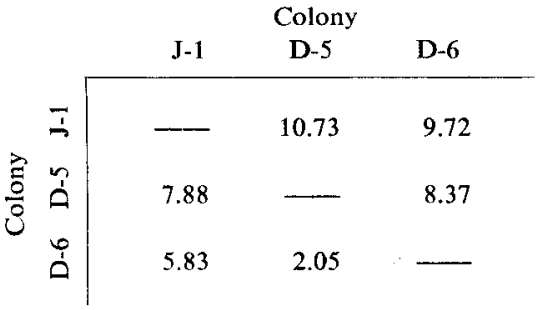

g) 24 June

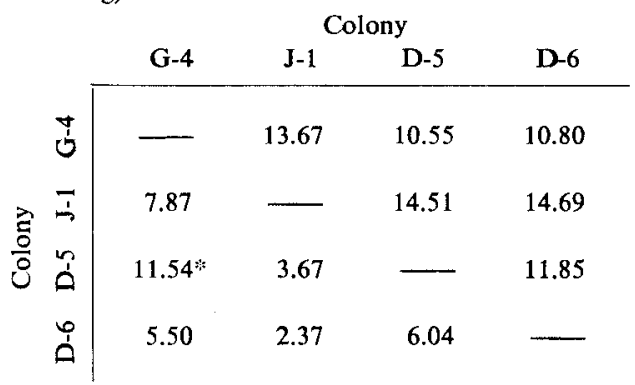

b) 3 June

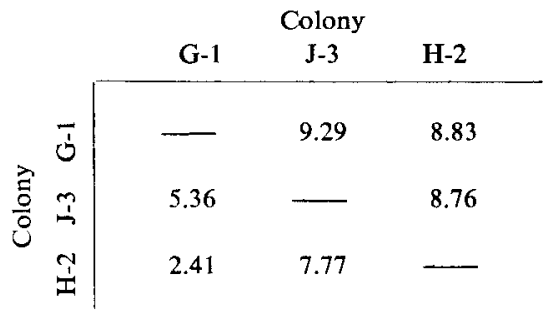

d) 7 June

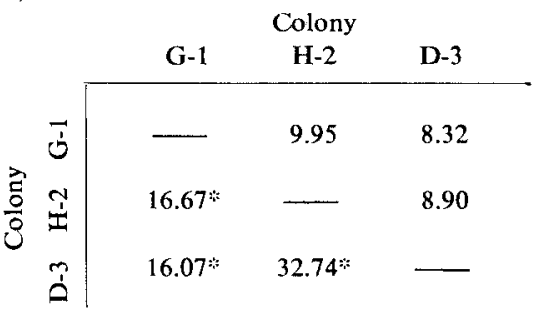

f) 17 June

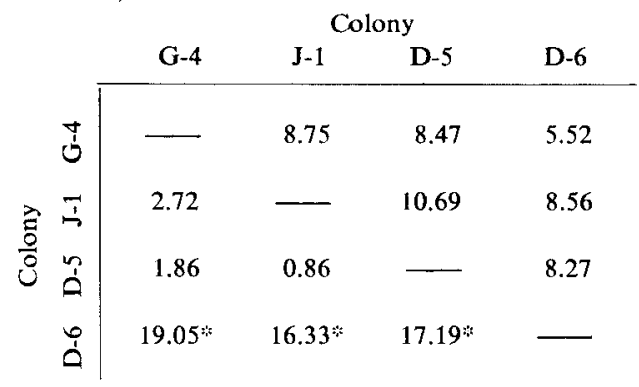

h) 29 June

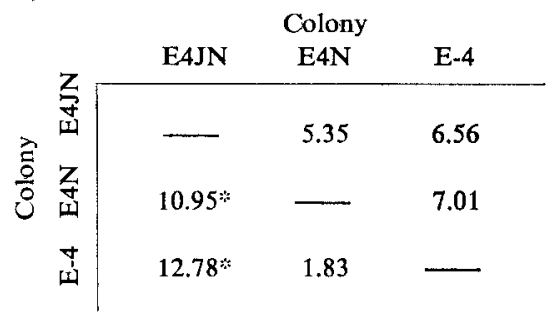

Differences between pairs of mean are given below the diagonal and corresponding minimum significant differences $(P<.05)$ between each pair of means are given above the diagonal. « $N$ in colony identifier indicates queenless nucleus colony (with 3000-5000 workers). Colonies, otherwise, are queenright with more than ca. 10000 workers. 


\section{TABle 2. - (continued)}

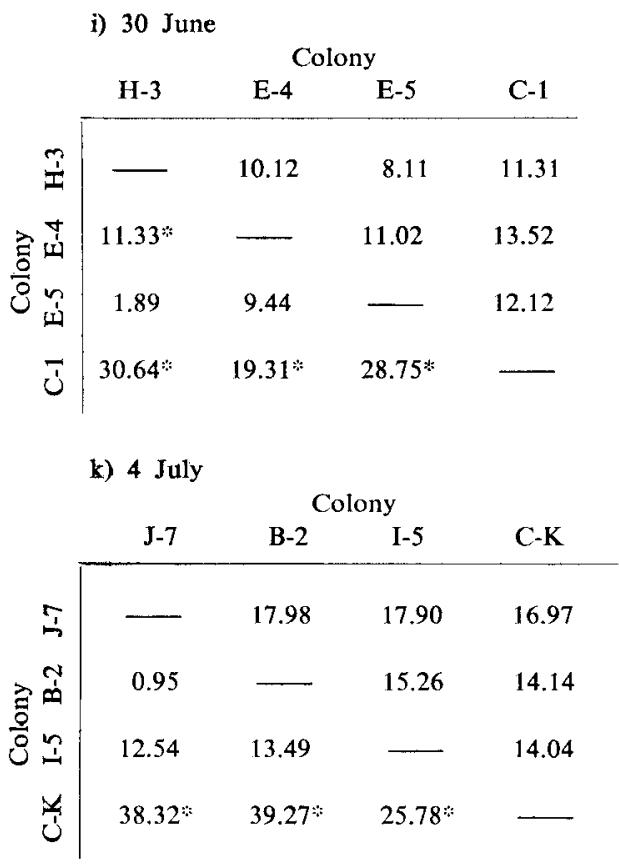

j) 2 July

\begin{tabular}{|c|c|c|c|c|}
\hline & & & & \\
\hline & $J-6$ & A-4 & B-2 & I-3 \\
\hline$\stackrel{2}{2}$ & - & 20.00 & 18.73 & 26.04 \\
\hline 音 & 7.96 & - & 20.40 & 20.39 \\
\hline 8 & 17.02 & $24.98=$ & - & 19.16 \\
\hline 2 & 9.14 & 17.10 & 7.88 & 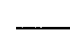 \\
\hline
\end{tabular}

m) 6 July

1) 5 July
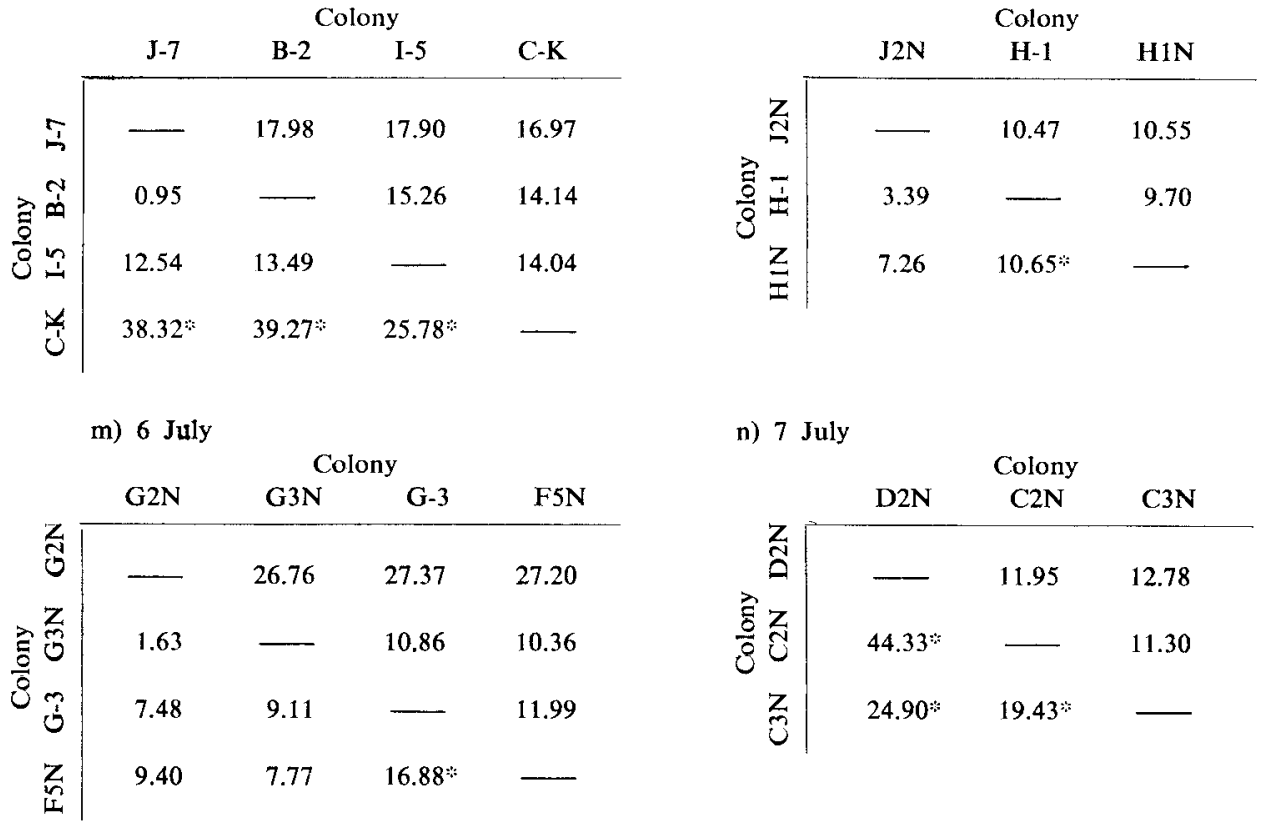

n) 7 July

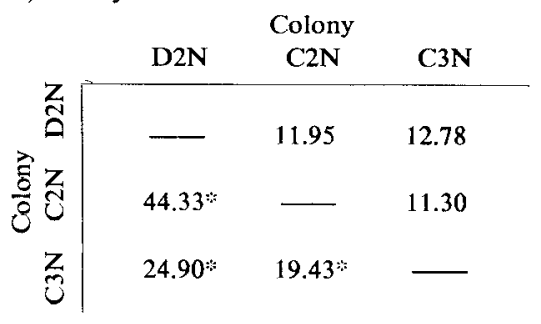

o) 12 July

\begin{tabular}{|c|c|c|c|c|}
\hline & \multicolumn{4}{|c|}{ Colony } \\
\hline & $\mathrm{H} 5 \mathrm{~N}$ & $\mathrm{~B} 4 \mathrm{~N}$ & $\mathrm{I} 6 \mathrm{~N}$ & FKSN \\
\hline & & 12.12 & 12.01 & 12.68 \\
\hline 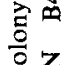 & $14.27 *$ & $\longrightarrow$ & 11.28 & 11.98 \\
\hline & 5.50 & 8.77 & 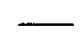 & 11.88 \\
\hline $\begin{array}{l}Z \\
Z \\
z \\
z\end{array}$ & 6.79 & 7.48 & 1.29 & $\ldots$ \\
\hline
\end{tabular}

p) 15 July

\begin{tabular}{|c|c|c|c|c|}
\hline & \multicolumn{4}{|c|}{ Colony } \\
\hline & J9N & AKN & A2N & $\mathrm{B} 1 \mathrm{~N}$ \\
\hline & - & 33.74 & 29.20 & 29.01 \\
\hline & $45.76 \%$ & - & 23.64 & 23.34 \\
\hline 宊 & 26.88 & 18.88 & - & 15.44 \\
\hline$\frac{z}{\not}$ & $41.46 *$ & 4.30 & 14.58 & - \\
\hline
\end{tabular}


How does weather affect drone flight behavior? Do large differences in mean departure times (among colonies) occur over a wide range of meteorological conditions or is there some optimum set of weather conditions necessary for differences to occur? Results indicate that differences in departure time means can be found over a wide range of weather conditions (RoweLL, 1985). Differences of 30 minutes or more in means of flight departure times occured on days where a) mean temperatures ranged from 27.50 to $34.36^{\circ} \mathrm{C}$, b) mean light intensities ranged from 5,400 to $26,500 \mathrm{ft}$-candles, c) mean cloudiness ranged from 0 to $40 \%$, and d) mean wind speeds ranged from 0.20 to $2.25 \mathrm{~m} / \mathrm{sec}$. Of the four meteorological factors (temperature, light intensity, cloudiness, and windspeed), only temperature was significantly correlated with mean departure time of drone flights (figure $2, \mathrm{r}=.626, \mathrm{n}=64, \mathrm{P}<.01$ ). Seasonal shifts in drone flight times are clearly associated with temperature change as suggested by TABER (1964).

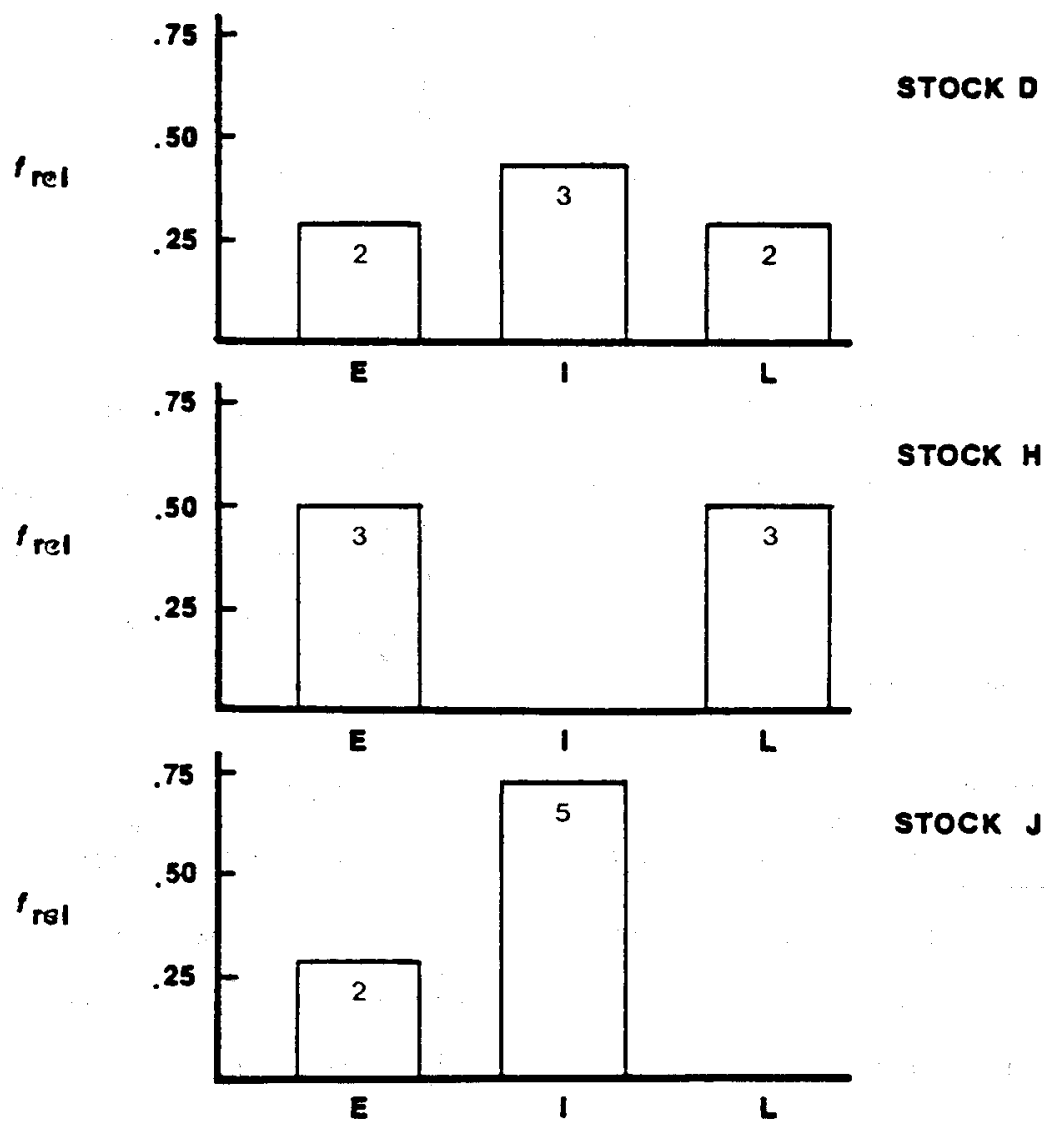

FIG. 1. - Comparative departure times of drones based on rank of colony means $\mathrm{E}=$ early, $\mathrm{I}=$ intermediate, $\mathrm{L}=$ late 


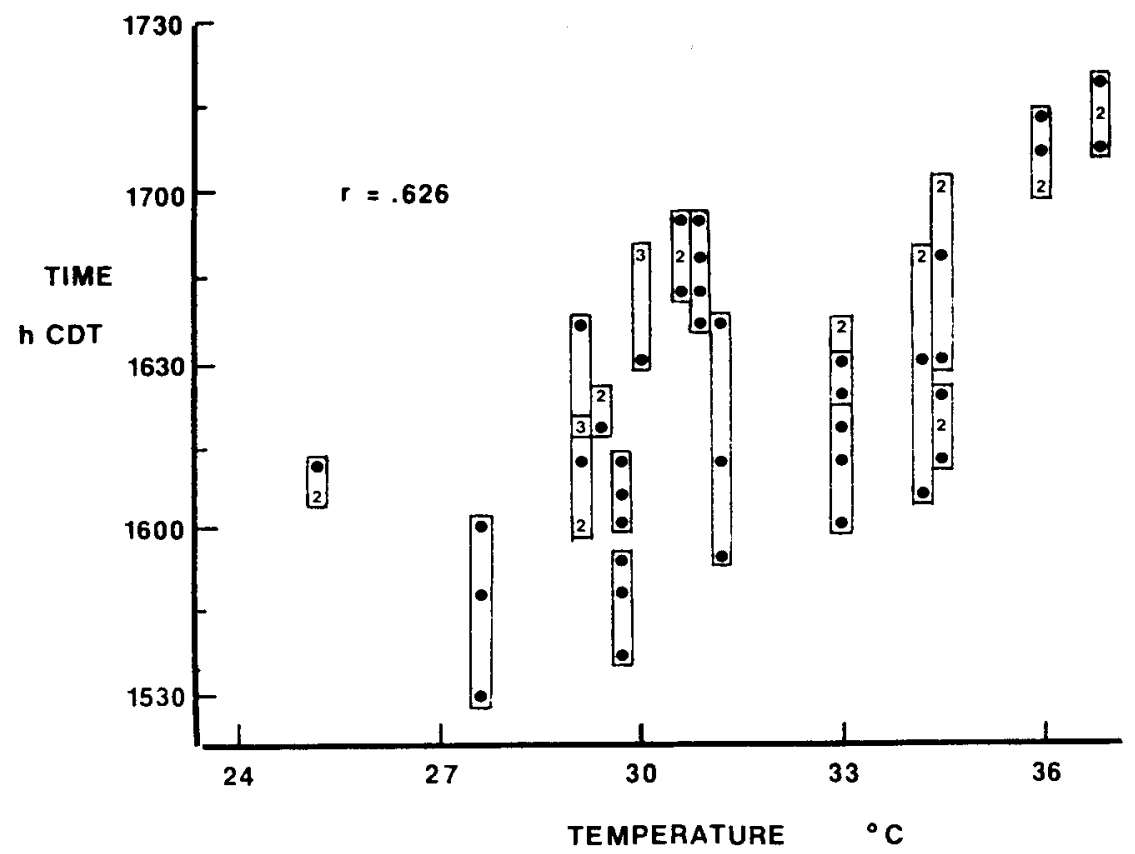

FIG. 2. - Mean departure time and temperature

Values for each day enclosed within rectangles.

Temperature is mean value during flight observation period each day.

Numbers replace dots if two or more values are the same

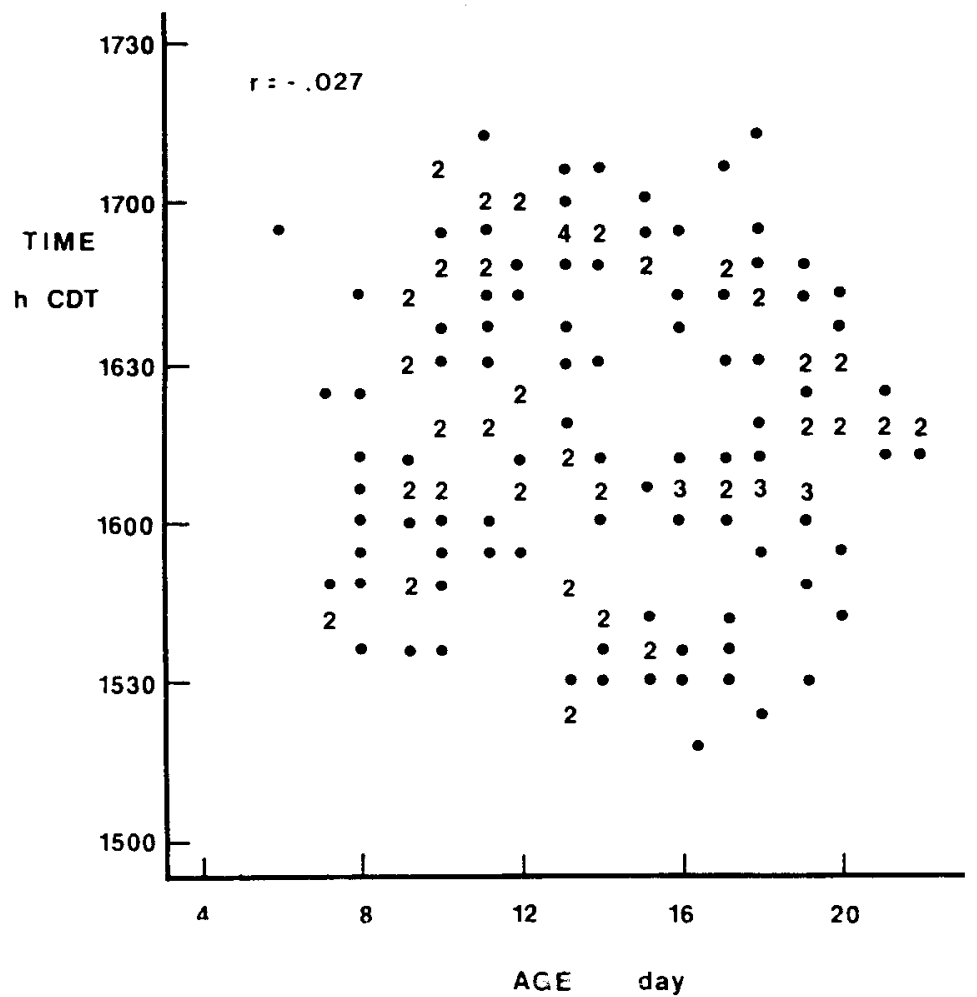

FIG. 3. - Mean departure time and drone age : standard colonies (queenright with more than ca. 10000 worker bees)

Numbers replace dots if two or more values are the same 


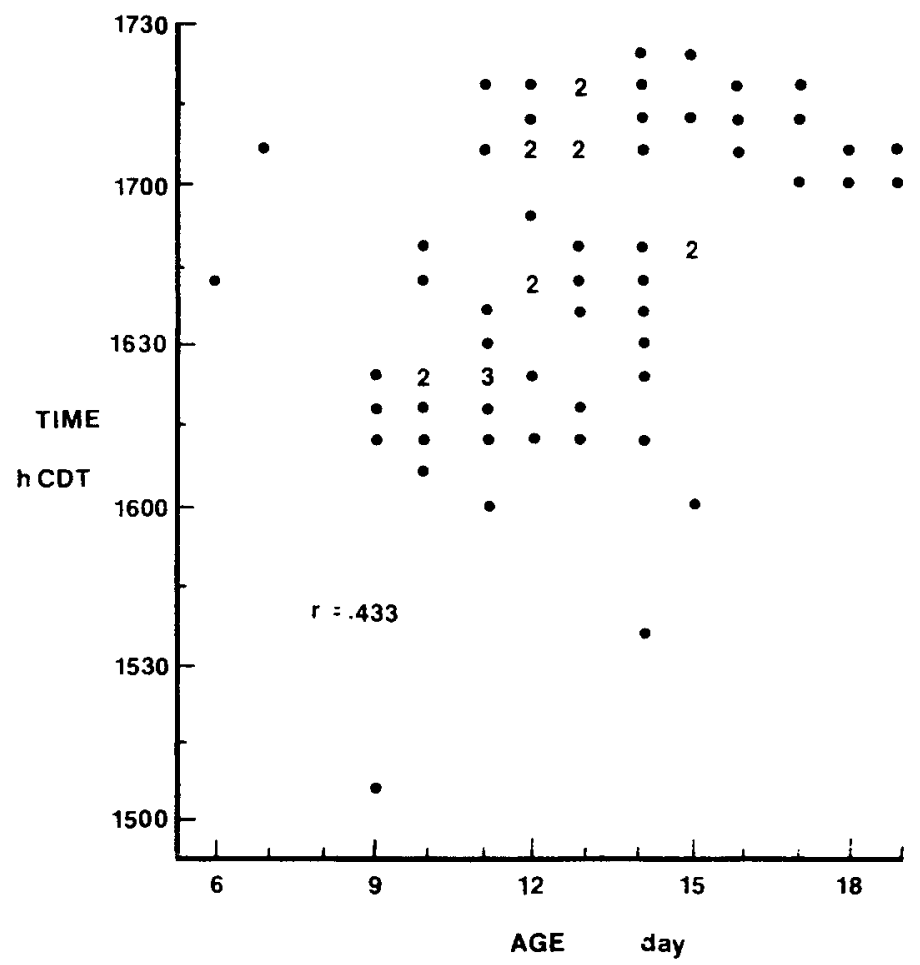

FIG. 4. - Mean departure times and drones ages: nucleus colonies (queenlees with 3000-5000 worker bees)

Numbers replace dots if two or more values are the same

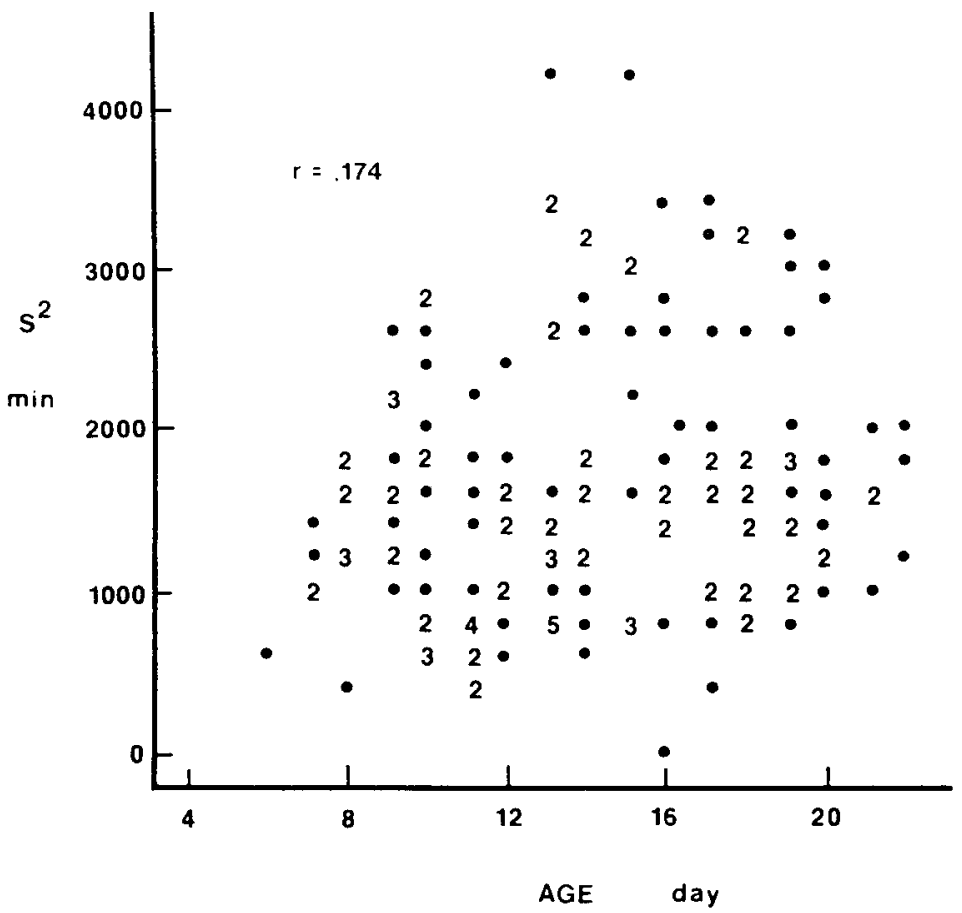

FIG. 5. - Durations of flight activity (based on magnitude of within-colony variance, $s^{2}$ ) and drone ages : standard colonies (queenright with more than ca. 10000 worker bees)

Numbers replace dots if two or more values are the same 
To what extent does age influence the time of day drones fly? The effects of age seem to depend on the presence of the queen and size of the colony. Among standard colonies, there was no significant correlation between drone age and mean departure time (figure $3, \mathrm{r}=-.027, \mathrm{n}=165, \mathrm{P}>.05$ ). But for drones housed in queenless nucleus colonies, departure times averaged later among older drones (figure $4, \mathrm{r}=.433, \mathrm{n}=67, \mathrm{P}<.01$ ). Differences between standard colonies and queenless nucleus colonies are somewhat obscured by the fact that most nucleus colony comparisons were made later in the summer (when temperatures were generally higher) than were comparisons of standard colonies. (See table 1 for specific dates of comparisons).

The effects of age on duration of flight activity (as measured by the magnitude of within-colony variance) were also quite different between standard and queenless nucleus colonies. Among standard colonies, duration of flight activity generally increased with age (figure $5, \mathrm{r}=.174, \mathrm{n}=165, \mathrm{P}<.05$ ). But for queenless nucleus colonies, duration of flight activity appeared to decrease with age, although not statistically significantly (figure $6, \mathrm{r}=-.179, \mathrm{n}=67, \mathrm{P}>.05$ ).

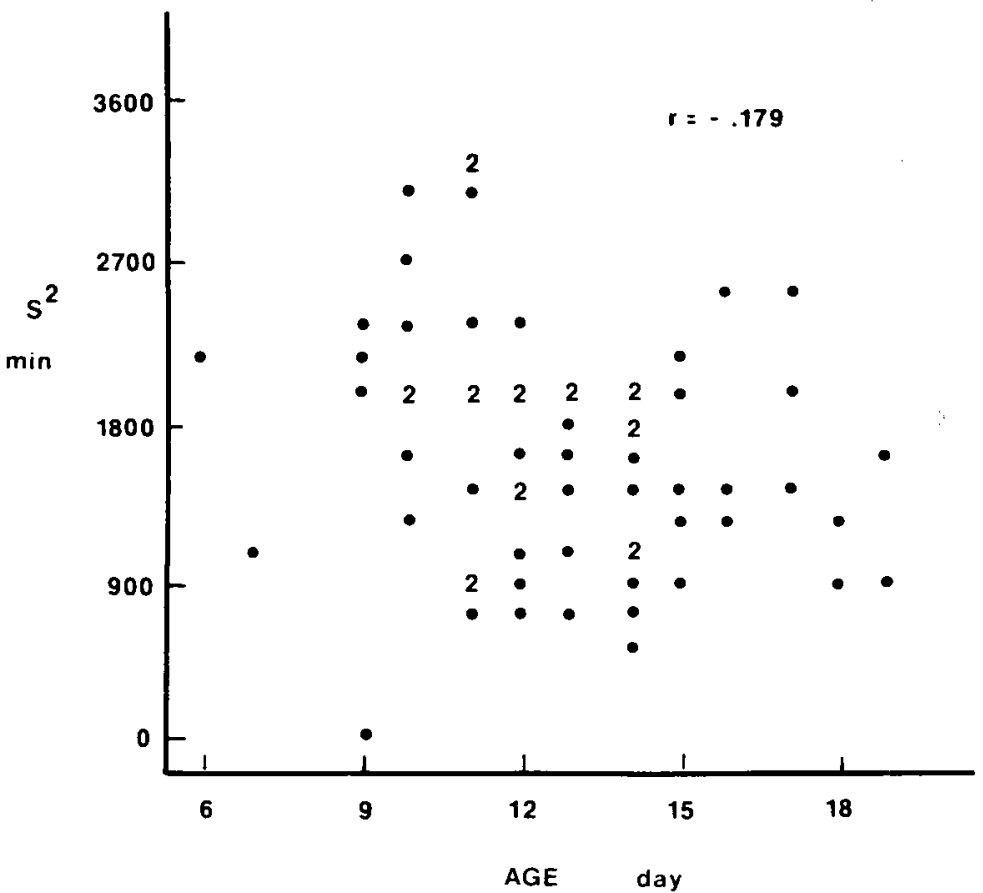

Fig. 6. - Durations of flight activity (based on magnitude of within-colony variances, $s^{2}$ ) and drone ages : nucleus colonies (queenless with 3000-5000 worker bees) 


\section{DISCUSSION AND CONCLUSIONS}

Patterns in drone mating flight times indicated that significant differences among colonies, in the time of day that drones fly, occur frequently. Significant differences in the duration of flight activity among colonies (based on withincolony variances) were also common. These differences in drone flight behavior were observed among colonies of different honey bee races but were also observed among colonies of the same race and even among colonies of the same commercial stock.

At present, no one race or commercial stock can be described as early or late in drone flight activity. Means and variances in drone departure times are highly variable both among and within races and also within commercial stocks. The variability in mean departure times and in duration of flight activities differs among races and among commercial stocks. Reasons for differential variability among races and stocks are not clear. Possible factors contributing to variability are discussed below.

Generalization about races of Apis mellifera, with regard to drone flight times, are somewhat limited. At best, one can conclude the CAR and LIG - Stock H drones tend to have greater variation in mean departure times and that hybrid MEL-LIG drones are comparatively less variable (i.e., they are most often observed to have intermediate flight times rather than early or late ones).

Similarly, one cannot describe commercial stocks strictly as early or late fliers. Of the 10 commercial stocks evaluated for drone flight times, four had colonies in all three categories (early, intermediate, and late - Stocks B, C, D, and $E$ ) when compared with other colonies on the same day. Five of the 10 stocks had colonies in just two flight time categories (early and intermediate - Stocks F and $J$, intermediate and late - Stocks A and G, and early and late - Stock H). And only one of the 10 (Stock I) had the same category (intermediate) throughout the study.

Large variation within races and stocks makes it seem unlikely that a commercially available stock will be identified as a consistent producer of only early- or late-flying drones. Of sixteen observation days on which statistical differences $(\mathrm{P}<.05)$ were detected among mean departure times in overall tests, six days involved differences between pairs of colonies of the same race, and three involved pairs from the same commercial stocks (tables 1 and 2). Differences between mean departure times of drones from the same commercial stocks were greater than 15 minutes on two occasions (17 June and 7 July). Such within-stock variation indicates the need to concentrate on differences among individual colonies rather than differences among races or stocks in an attempt to select for drone mating flight times. 
Variation among colonies in flight times of drones was not restricted to any narrow set of meteorological conditions. Differences of 30 minutes or more in mean departure times occurred over a wide range of temperatures, light intensities, windspeeds, and cloud conditions (Rowell, 1985). Drones commonly fly at temperatures above $19^{\circ} \mathrm{C}$ (RutTner, 1956 ; Drescher, 1969; Bol'ShaKova, 1978). Between $15-28{ }^{\circ} \mathrm{C}$, the duration of flights increases with increasing temperatures (Verbeek and Drescher, 1984). The upper temperature limit has not been rigorously quantified but probably is near $38^{\circ} \mathrm{C}$. Differences of greater than 30 minutes among mean departure times for colonies were observed at mean temperatures (during flight period) of $27.50-34.36^{\circ} \mathrm{C}$. Unfortunately, the frequency of observations at lower temperatures was limited by typically warm Kansas weather during June and July 1983 . Windspeeds of $4-6 \mathrm{~m} / \mathrm{sec}$ and more have been reported to substantially reduce mating success and flight activity of queens and drones (RuttNer, 1956 ; Fletcher and Tribe, 1977 ; Bol'shakova, 1978). Differences among mean departure times (greater than 30 minutes) occurred at windspeeds of $0.20-2.25 \mathrm{~m} / \mathrm{sec}$. Bol'SHAKOVA (1978) reported that drone flight activity is unaffected by cloudiness at a range of $0-8$ on a $0-10$ scale of increasing cloudiness. Under conditions of complete cloud cover, drones did not fly (Bol'shakova, 1978). Results from the present study indicate that substantial differences in mean departure times occur over a range of $0,40 \%$ cloudiness. Differences of greater than 30 minutes between mean departure times were also observed at light intensities of 5,400-26,500 ft-candles.

Flight time means, among standard colonies, were not dependent on drone age $(\mathrm{r}=-.027, \mathrm{n}=165, \mathrm{P}>.05)$. However, duration of flight activity (as measured by magnitude of within-colony variance) increased with drone age among standard colonies $(\mathrm{r}=.174, \mathrm{n}=165, \mathrm{P}<.05)$. Longer duration of flight activity associated with increasing age is probably a function of maturation of flight muscle and possibly increased tolerance to meteorological extremes. Also, longer duration of flight activity among older drones is probably associated with decreased retention of them by workers. Worker bees give preferential care to younger drones and under conditions of resource stress sacrifice older drones first (JAYCOX, 1961 ; СовEY, 1983).

A very different age relationship was observed for drones housed in queenless nucleus colonies (having 3000-5000 workers). Among nucleus colonies, mean departure time was highly dependent on drone age, that is, older drones flew later in the day $(r=.433, n=67, P<.01)$. Also, duration of flight activity did not increase with drone age, as with standard colonies, but instead showed a slight decrease and no significant correlation $(\mathrm{r}=-.179, \mathrm{n}=67, \mathrm{P}>.05)$. A comparison of these results with those of standard colonies is confounded, unfortunately, by the fact that nucleus colonies were observed later in the summer when temperatures were generally higher. Worker - drone behavioral interactions are probably 
modified by the absence of the queen. Additional observations of worker - drone interactions and worker tolerance of drones in queenless and queenright colonies may help to explain these results.

Does the observed variation among colonies, in mating flight times of drones, have a genetic basis? (1) Other studies on drone flight behavior have shown a range of differences in the time of day that drones fly (LAVREKHIN, 1960; Drescher, 1969 ; Tuchashvili, 1969; Koeniger and WiJayagunasekera, 1976 ; TAYlOR, KingSOlVER and OtIS, in press). These studies have compared different species of Apis and also different geographic races of Apis mellifera. As one might expect, interspecific differences in drone flight times are much larger than those found within $A$. mellifera. Greater interspecific variation indirectly suggests that mating flight times could be genetically based.

(2) On the basis of limited observations, drones from colonies observed more than once showed repeated early or late flight times. For example, those from colony G-4 consistently flew later than from colonies J-1, D-5, or D-6 (17 and 24 June). Drones of colony J-4 flew earlier than those of colony H-4 (28 May and 9 June). Repeatability of behavioral and physiologically based traits have been shown to indicate heritability in a number of studies (PerRins and Jones, 1974 ; OJANen et al., 1979; Findley and CoOKe, 1982).

(3) The consistencies observed so far among individual colonies may be associated with genetically based differences in drone flight physiology and possibly worker behavior. Regarding flight physiology, MoRITZ (1982) discovered that drones of inbred queens show a significant inbreeding depression in metabolism: Inbreeding affects oxygen consumption and the inbreeding depression is related to disequilibria among activity levels of several enzyme systems. MoriTz (19.81) also found that inbreeding affects drone flight behavior in that it reduces flight frequency and duration.

(4) The genetic component of variation in drone flight times appears to be complex and may involve drone morphology, physiology, and behavioral interactions between workers bees and drones. Additional studies might show significant associations between drone flight times and factors such as body temperature, body color, metabolic rate, mortality associated with heat stress, temperature of minimal flight activity, retention of drones by worker bees, and presence or absence of the queen.

Environmental and biological factors contributing to variation in drone flight times may interact with one another (for example, ambient temperature and drone flight physiology, or resource availability and worker-drone behavior). Consequently, genetic and environmental components of this variation may interact. Given the fact that studies of flight-time are complicated by such interactions, it 
appears that a late line-early line breeding program which concentrates on individual colony differences and selects from unrelated stocks might demonstrate the genetic bas:s of variation in flight times most conclusively.

\title{
ACKNOWLEDGEMENTS
}

Andrew DeValpine and Dee Woessner provided substantial assistance in recording drone flight observations, for which we are grateful. Andrew DeValPINE also helped with the computer data entry. Funding for this project was provided by University of Kansas Graduate Research Funds No. 3398-0038 and No. 3505-0038 to O. R. TAYLoR, Jr., and also by a grant from Sigma $\mathrm{Xi}$.

Received for publication in April 1985. Accepted for publication in October 1985.

\section{RÉSUME}

\author{
VARIABILITE DE LA PERIODE DES VOLS DE FECONDATION \\ CHEZ LES MALES D'ABEILLES DE SOUCHES COMMERCIALES
}

L'étude porte sur la variabilité inter et intra-souches du moment de la journée où volent les mâles d'abeilles. La mesure de cette variabilité est un premier pas vers un plan de sélection de l'abeille destiné à développer une souche commerciale dont les mâles volent tard. De tels mâles peuvent se montrer utiles pour optimiser l'hybridation entre les abeilles africaines et les abeilles européennes en Amérique (voir aussi TaYlor, Kingsolver et OtIS, sous presse).

\section{Méthodes}

Dix souches provenant des races suivantes ont été sélectionnées : Apis mellifica carnica (souches A, B et C), A.m. caucasica (souches D, E et F), A.m. ligustica (souches G, H et I) et A.m. mellifica-ligustica (souche J). Les 5 ruchers expérimentaux de cette étude comportaient chacun des colonies provenant d'au moins 4 souches. Il y avait au total 45 colonies. Les ruchers étaient situés près de Lawrence, dans le Kansas $\left(38,58^{\circ} \mathrm{N} ; 95,14^{\circ} \mathrm{W}\right)$

Les différences physiques entre les colonies de chaque rucher ont été minimisées afin de réduire la variabilité non génétique des heures moyennes d'envol. Les entrées de ruche ont été orientées dans la même direction (en général vers le sud). L'exposition au vent était à peu près la même au sein de chaque rucher. Les différences d'ombre et d'insolation ont été également minimisées.

Les mâles ont été marqués individuellement sur le tergite avec 1 ou 2 points de peinture au venirs séchant rapidement afin d'identifier I'âge et la colonie d'origine. On a marqué 400 mâles par colonie au fur et à mesure de leur émergence durant 4 jours consécutifs.

Dans cette étude la principale variable est la répartition de la fréquence des envols de mâles dans le temps. L'heure de départ (à la minute près) et l’âge des mâles ont été notés par des observateurs assis près de l'entrée des ruches de $14 \mathrm{~h}$ à $18 \mathrm{~h}$ (heure locale).

Les données météorologiques (température, intensité lumineuse incidente, nébulosité et vitesse du vent) ont été enregistrées sur l'emplacement des ruchers toutes les 15 minutes durant chaque 
période d'observation. Les observations d'envol des mâles ont été faites sur des colonies possédant 1 reine et installées dans des ruches 10 cadres avec 1 hausse ainsi que sur des colonies orphelines dans des ruchettes 5 cadres.

\section{Résultats}

On a trouvé des différences importantes dans les heures moyennes d'envol et dans les variances intra-colonies des heures d'envol pour un même jour. En comparant l'activité de vol de 3 à 4 colonies chaque jour, on a obtenu des différences significatives dans les heures moyennes d'envol pour 16 jours, sur 20 jours d'observation (valeur de $F^{*}, p<0,05$, tabl. 1). Des différences significatives dans les variances intra-colonies ont été notées pour 14 jours sur 20 jours d'observation (valeurs de $W_{0}$ $\mathrm{p}<0,05$, tabl. 1).

On a trouvé des différences significatives $(\mathrm{p}<0,05)$ dans les couples de moyennes parmi les colonies de race différente (tabl. 2 : a, d, f, g, h, i, k, m, n, o et p), parmi les colonies de souches commerciales différentes mais de même race (tabl. $2: \mathbf{d}$, j et $k$ ) et parmi les colonies de la même souche commerciale (tabl. 2 : f, 1 et $\mathrm{n}$ ).

En classant les moyennes à l'intérieur de chaque jour (précoce, moyen, tardif) et en comparant globalement tous les jours où des différences significatives (test $F *, p<0,01$ ) sont apparues, il ressort que certaines souches ont des périodes de vol en prédominance moyennes mais que pour d'autres les périodes de vol sont beaucoup plus extrêmes soit précoces, soit tardives (fig. 1).

Des 4 facteurs météorologiques, seule la température a été corrélée de façon significative avec l'heure moyenne d'envol (fig. $2, \mathrm{r}=0,626, \mathrm{n}=64, \mathrm{p}<0,01$ ).

Parmi les colonies standard, il n'y a pas eu de corrélation significative entre l'âge des mâles et l'heure moyenne d'envol (fig. $3, \mathrm{r}=-0,027, \mathrm{n}=165, \mathrm{p}>0,05$ ). Mais pour les mâles des ruchettes orphelines, les heures d'envol étaient en moyenne plus tardives pour les mâles plus âgés (fig. $4, \mathrm{r}=0,433, \mathrm{n}=67, \mathrm{p}<0,01$ ).

Parmi les colonies standard, la durée de l'activité d'envol s'est généralement accrue avec l'âge (fig. $5, \mathrm{r}=0,174, \mathrm{n}=165, \mathrm{p}<0,05$ ), néanmoins la durée de l'activité de vol des mâles a semblé diminuer avec lâge bien que de façon non statistiquement significative (fig. $6, r=-0,179$, $\mathrm{n}=67, \mathrm{p}>0,05)$.

\section{Discussion et conclusion}

La répartition des périodes des vols de fécondation indique qu'il existe fréquemment des diffé ences significatives parmi les colonies dans le moment de la journée où les mâles volent. Pourtant on n'a pu caractériser aucune race ni souche commerciale, parmi celles étudiées, comme étant précoce ou tardive dans l'activité de vol de leurs mâles. Les moyennes et les variances des heures d'envol des mâles sont hautement variables entre et au sein des races et aussi au sein des souches commerciales. Il semble improbable, d'après les fortes différences qui existent au sein des races et des souches, que l'on puisse caractériser une souche comme produisant uniformément des mâles à l'activité de vol précoce ou tardive.

Parmi les conditions météorologiques étudiées, seule la température a été corrélée significativement avec l'heure moyenne d'envol des mâles tout au long de la saison (fin mai à mi-juin). Les moyennes des heures d'envol, chez les grosses colonies avec reine, sont indépendantes de l'âge des mâles, mais chez les petites colonies orphelines, elles en dépendent fortement. De telles différences peuvent être liées aux interactions comportementales ouvrière-mâle influencées par la présence ou l'absence de la reine.

La composante génétique de la variabilité des périodes de vol des mâles pourrait être complexe et inclure la morphologie, la physiologie des mâles et peut-être des interactions comportementales entre les ouvrières et les mâles. Un plan de sélection «lignée précoce - lignée tardive » qui se 
concentrerait sur les différences individuelles des colonies et effectuerait une sélection à partir de souches non parentes, pourrait démontrer la base génétique de la variabilité des périodes de vol des mâles de manière plus concluante.

\section{ZUSAMMENFASSUNG}

\section{VARIATION IN DEN DROHNENFLUGZEITEN BEI KOMMERZIELLEN BIENENSTAMMEN}

Dies ist eine Untersuchung der Variation in den Tagesstunden, zu denen die Drohnen fliegen, zwischen und innerhalb kommerzieller Bienenstämme. In der Untersuchung wird die erfaßbare Variation der Flugzeiten der Drohnen gemessen - als erster Schritt zu einem Bienenzüchtungsprogramm mit dem Ziel, einen kommerziellen Stamm mit spätfliegenden Drohnen zu entwickeln. Solche spätfliegenden Drohnen könnten sich für eine Steigerung der Hybridisierung zwischen afrikanischen und europäischen Bienen in Amerika als nützlich erweisen (siehe auch TAYLOR, KINGSOLVER and OTIS, in Druck).

\section{Methoden}

Zehn Stämme von den folgenden Bienenrassen wurden selektiert : Apis mellifera carnica (Stämme A, B und C, A.m. caucasica (Stämme D, E und F), A.m. ligustica (Stämme G, H und I) und A.m. mellifera-ligustica (Stamm J). Die fünf Versuchsstände, die für dieses Experiment benutzt wurden, enthielten jeder vier oder mehr von diesen Stämmen. Insgesamt standen 45 Völker zur Verfügung. Die Bienenstände befanden sich in der Nähe von Lawrence, Kansas $\left(38.58^{\circ} \mathrm{N}, 95.14^{\circ} \mathrm{W}\right)$.

Die physischen Unterschiede zwischen den Völkern wurden so gering als möglich gehalten, um die nichtgenetischen Variation in der mittleren Abflugzeit zu verringern. Die Fluglöcher wurde alle in dieselbe Richtung orientiert (nach Süden). Die Exposition gegenüber dem Wind war innerhalb der Stände ungefähr, dieselbe. Ebenso wurden Unterschiede in Besonnung und Schatten so gering als möglich gehalten.

Die Drohnen wurden auf dèm Rückenschild mit einem oder zwei Tupfen eines schnelltrocknenden Emaillackes individuell markiert, um Alter und Herkunfstvolk zu erkennen. 400 Drohnen wurden pro Volk an vier aufeinanderfolgenden Tagen unmittelbar nach dem Schlüpfen markiert. Die wichtigste Variable in dieser Studie war die Häufigkeitsverteilung des Drohnenabfluges über die Zeit. Abflugzeit (nach der nächsten vollen Minute) und Alter der Drohnen wurden von Beobachtern notiert, die zwischen 14.00 und $18.00 \mathrm{~h}$ zentraler Sommerzeit neben den Fluglöchern postiert waren. Meteorologische Daten (Temperatur, einfallende Lichtintensität, Bewölkung und Windgeschwindigkeit) wurden am Ort des Bienenstandes während jeder Beobachtungszeit alle $15 \mathrm{~min}$. registriert. Die Beobachtung der Drohnenabflüge wurden an weiselrichtigen Völkern in Bienenstöcken mit zwei Räumen zu 10 Rähmchen und an weisellosen Völkern in Kästen mit fünf Waben durchgeführt.

\section{Resultate}

Zwischen den am selben Tag verglichenen Völkern wurden häufig beträchtliche Unterschiede in der mittleren Abflugzeit und in den Varianzen der Abflugzeit innerhalb der Völker gefunden. Von insgesamt 20 Beobachtungstagen, an denen die Drohnenflugaktivität von drei bis vier Völkern pro Tag verglichen wurde, konnten an 16 Tagen signifikante Unterschiede in der mittleren Abflugzeit gefunden werden ( $F *$ Werte, $P<0,05$, Tab. 1). Signifikante Unterschiede in der Varianz innerhalb der Völker wurden bei 14 von 20 Beobachtungstagen gefunden $\left(W_{0}\right.$ Werte, $\mathrm{P}<0,05$, Tab. 1).

Signifikante Unterschiede $(P<0,05)$ wurden zwischen Paaren von Mittelwerten von Völkern verschiedener Rassen (Tab. $2: a, d, f, g, h, i, k, m, n, o$ und p), zwischen Völkern von verschiedenen 
kommerziellen Stämmen derselben Rasse (Tab. 2 : d, j und k) und zwischen Völkern desselben kommerziellen Stammes (Tab. $2:$ f, 1 und n) gefunden.

Durch Klassifizierung der Mittel innerhalb eines jeden Tages (früh, mittel oder spät) und durch kollektiven Vergleich aller Tage, an denen signifikante Unterschiede gefunden wurden ( $F^{*}$ Test, $\mathbf{P}<0,01$ ) ergab sich, daß manche Stämme überwiegend mittlere Flugzeiten hatten, andere aber weit mehr extreme Mittelwerte der Flugzeit, sowohl früh wie spät (Abb. 1).

Von den vier meteorologischen Faktoren (Temperatur, Lichtintensität, Bewölkung und Windgeschwindigkeit) war nur die Temperatur signifikant mit der mittleren Abflugzeit der Drohnen korreliert (Abb. 2, $r=0,626, n=64, P<0,01$ ).

Bei den Normalvölkern bestand keine signifikante Korrelation zwischen Drohnenalter und mittlerer Abflugzeit (Abb. 3, $\mathrm{r}=-0,027, \mathrm{n}=165, \mathrm{P}>0,05$ ). Aber bei den Drohnen in weisellosen Völkern lag das Mittel für ältere Drohnen später (Abb. 4, $r=0,433, n=67, P<0,01$ ).

Bei Normalvölkern nahm die Dauer der Flugaktivität allgemein mit dem Alter zu (Abb. 5, $\mathrm{r}=0,174, \mathrm{n}=165, \mathrm{P}<0,05$ ), die Dauer der Drohnenflugaktivität schien jedoch mit dem Alter zu sinken, wenn auch nicht statistisch signifikant (Abb. 6, $\mathrm{r}=-0.179, \mathrm{n}=67, \mathrm{P}>0,05$ ).

\section{Diskussion und Schlußfolgerungen}

Die Muster der Drohnenflugzeiten weisen darauf hin, daß hinsichtlich der Tagesstunden, zu denen die Drohnen fliegen, zwischen den Völkern häufig signifikante Unterschiede auftreten. Es konnte jedoch nicht einige der untersuchten Rassen oder der kommerziellen Stämme entweder als «früh» oder «spät» in der Drohnenflugzeit eingestuft werden. Mittelwerte und Varianzen der Drohnenabflugzeiten waren sowohl zwischen wie innerhalb der Rassen und auch innerhalb der kommerziellen Stämme hoch variabel. Die großen Unterschiede innerhalb der Rassen und Stämme machen es unwahrscheinlich, daß ein kommerziell erhältlicher Stamm als verläßlicher Erzeuger entweder früh-oder spätfliegender Drohnen bestimmt werden kann.

Von den untersuchten meteorologischen Bedingungen war nur die Temperatur im Verlaufe der Saison (Ende Mai - Mitte Juli) mit der mittleren Abflugzeit der Drohnen signifikant korreliert. Die Mittelwerte der Flugzeiten waren bei starken weiselrichtigen Völkern nicht vom Drohnenalter abhängig. In kleinen weisellosen Völkern hingen jedoch die mittleren Abflugzeiten stark vom Drohnenalter $a b$. Solche Unterschiede in dem Zusammenhang Drohnenflugzeit - Alter könnten mit Welchselwirkungen zwischen Arbeiterinnen und Drohnen im Verhalten gekoppelt sein, beeinflußt von der Gegenwart oder Abwesenheit der Königin.

Die genetische Komponente in der Variation der Drohnenflugzeit könnte komplex sein und sowohl Morphologie und Physiologie der Drohnen wie auch vielleicht Wechselwirkungen im Verhalten von Arbeiterinnen und Drohnen beinhalten. Ein Zuchtprogramm "späte Linie - frühe Linie», das sich auf die Unterschiede individueller Völker konzentriert und aus nichtverwandten Stämmen selektiert, könnte die genetische Grundlage der Variation in der Drohnenflugzeit sehr überzeugend darlegen.

\section{BIBLIOGRAPHY}

Adam Brother, Connor L., 1984. - Buckfast bees, problems with Amercan bees, and the future of bee breeding. The Speedy Bee, 13, 7-9.

Bol'shakova M.D., 1978. - The flight of honey bee drones, Apis mellifera L. (Hymenoptera, Apidae), to the queen in relation to various ecological factors. Entomological Review, 56, 53-56.

Brown M.B., Forsythe A.B., 1974 a. - The small sample behavior of some statistics which test the equality of several means. Technometrics, 16, 129-132. 
Brown M.B., Forsythe A.B., 1974 b. - Robust tests for the equality of variances. J. Amer. Statistical Assoc., 69, 364-367.

Butler C.G., Fairey E.M., 1964. - Pheromones of the honeybee : Biological studies of the mandibular gland secretion of the queen. J. Apic. Res., 3, 65-76.

Cobey S., 1983. - Drone rearing for instrumental insemination. Amer. Bee J., 123, 284-289.

Dixon W.J., 1981. - Program BMDP-7D. In : Dixon W.J. et al. : BMDP Statistical Software, p. 105-107. University of California Press, Berkeley.

Drescher W., 1969. - Die Flugaktivität von Drohnen der Rasse Apis mellifica carnica L. und A.m. ligustica L. Z. Bienenforsch., 9, 390-409.

Findley C.S., CoOKE F., 1982. - Breeding synchrony in the lesser snow goose (Anser caerulescens caerulescens). 1. Genetic and environmental components of hatch date variability and their effects on hatch synchrony. Evolution, 36, 342-351.

Fletcher D.J.C., Tribe G.D., 1977. - Natural emergency queen rearing by Apis mellifera adansonii and its relevance for successful queen production by beekeepers, II. In : FLETCHER D.J.C. : African Bees Apimondia International Symposium, p. 161-168. Apimondia, Pretoria.

Fukuda H., Ohtani T., 1977. - Survival and life span of drone honey bees. Res. Popul. Ecol., 19, 51-68.

GARY N.E., 1963, - Observations of mating behavior of the honeybee. J. Apic. Res., 2, 3-13.

Howell D.E., Usinger R.L., 1933. - Observations on the flight and length of life of drone bees. Ann. Entomol. Soc. Amer., 26, 239-246.

JAYCOX E.R., 1961. - The effects of various foods and temperatures on sexual maturation of the drone honey bee (Apis mellifera). Ann. Entomol. Soc, Amer., 54, 519-523.

Kofniger N., Wijayagunasekera H.N.P., 1976. - Time of drone flight in the three Asiatic honey bee species (Apis cerana, Apis florea, Apis dorsata). J. Apic. Res., 15, 67-71.

LAVREkHin F.A., 1960. - Comparative observations on the flight activity of drones. [In Russian]. Pchelovodstvo, 37, 43-45. Translation in U.S. Bee Culture Library, Beltsville, Maryland. Abstract in Apicultural Abstr. 1963. Vol. 14, 21.

Mikhallov A.S., 1928. - On drone flight activity. [In Russian]. Opytnaia Paseka, 3, $209-214$. Translation in U.S. Bee Culture Library, Beltsville, Maryland.

MORITz R.F.A., 1981. - Der Einfluss der Inzucht auf die Fitness der Drohnen von Apis mellifera carnica. Apidologie, 12, 41-55.

Moritz R.F.A., 1982. - Inzuchteffekte auf den Stoffwechsel von Drohnen (Apis mellifera carnica). Z. Tierzuechtung und Zuechtungsbiol., 99, 69-80.

Oertel E., 1956. - Observations on the flight of drone honey bees. Ann. Entomol. Soc. Amer., 49, 497-500.

Ojanen M., Orell M., Väisinen R.A., 1979. - Role of heredity in egg size variation in the Great Tit Parus major and the Pied Flycatcher Ficedula hypoleuca. Ornis Scand., 10, 22-28.

Perrias C.M., Jones P.J., 1974. - The inheritance of clutch size in the Great Tit (Parus major L.). Condor, 76, 225-229.

Rohlf F.J., 1983. - Program MCHETV. In : Rohlf F.J. : BIOM-PC : A package of statistical programs to accompany the text BIOMETRY. State University of New York, Stony Brook, New York, U.S.A.

Rowell G.A., 1985. - Variation in drone mating flight times among commercial honey bee stocks. M.A. Thesis. University of Kansas, Lawrence, Kansas, U.S.A.

Ruttner F., 1956. - The mating of the honey bee. Bee World, 37, 3-15.

Ruttner F., 1966. - The life and flight activity of drones. Bee World, 47, 93-100. 
Ruttner F., Ruttner H., 1966. - Untersuchungen über die Flugaktivität und das Paarungsverhalten der Drohnen. Z. Bienenforsch., 8, 332-354.

Sokal R.R., Rohlf F.J., 1981. - Biometry. W.H. Freeman and Co., San Francisco.

TABER S., 1964. - Factors influencing the circadian flight rhythm of drone honey bees. Ann. Entomol. Soc. Amer., 57, 769-775.

TaYlor O.R., Kingsolver R,, Otis G. (In press). - A neutral mating model for honey bees (Apis mellifera).

Tuchashvilı S.M., 1969. - Flight activity of drones of different races. [In Russian]. Pchelovodstvo, 10, 16-17. Translation from North of Scotland College of Agriculture.

Van Praagh J.P., Ribi W., Wehrhahn C., Wittmann D., 1980 . - Drone bees fixate the queen with the dorsal frontal part of their compound eyes. J. Comp. Physiol, 136, 263-266.

VerbeeK B., Drescher W., 1984. - Einfluss von Umweltfaktoren auf die Drohnenflugaktivität. Apidologie, 15, 277.

Witherell P.C., 1971. - Duration of flight and of interflight time of drone honey bces, Apis mellifera. Ann. Entomoll. Soc. Amer., 64, 609-612. 